\title{
Biochar Derived from the Dry, Solid Fraction of Pig Manure as Potential Fertilizer for Poor and Contaminated Soils
}

\author{
Jens Maggen ${ }^{1}$, Robert Carleer ${ }^{1}$, Jan Yperman ${ }^{1}$, Alain De Vocht ${ }^{2,3}$, Sonja Schreurs ${ }^{4}$, Guy Reggers ${ }^{1} \&$ Elsy Thijsen ${ }^{1}$ \\ ${ }^{1}$ Research Group of Applied and Analytical Chemistry, Hasselt University, Diepenbeek, Belgium \\ ${ }^{2}$ Research Group of Environmental Biology, Hasselt University, Diepenbeek, Belgium \\ ${ }^{3}$ Research Group of Bio-Research, PXL University College, Diepenbeek, Belgium \\ ${ }^{4}$ Research Group of NuTeC, Hasselt University, Diepenbeek, Belgium \\ Correspondence: Jens Maggen, Research Group of Applied and Analytical Chemistry, Hasselt University, \\ Agoralaan Gebouw D, 3590 Diepenbeek, Belgium. Tel: 321-126-8211. E-mail: jens.maggen@uhasselt.be
}

\author{
Received: February 15, 2017 Accepted: March 11, 2017 Online Published: April 19, 2017 \\ doi:10.5539/sar.v6n2p167 URL: https://doi.org/10.5539/sar.v6n2p167
}

\begin{abstract}
Pig manure results in the release of $\mathrm{NH}_{3}, \mathrm{NO}_{\mathrm{x}}$, volatile organic compounds and odour nuisance. Pyrolysis of dried pig manure can be considered as an economical viable approach converting this agricultural waste into value added products. The produced amendment biochar can be used as a slow release fertilizer with high concentration of $\mathrm{N}, \mathrm{K}$ and $\mathrm{P}$ and has beneficial effects as carbon sequester and improver of soil quality and crop productivity. It is proved that a $2 \mathrm{wt} . \%$ blending of biochar with a poor soil affects positively plant growth and crops (dwarf beans), and worm (Eisenia fetida) survival and production. Additional, available heavy metals are immobilised in the biochar and not leachable. The resulting biochar therefore offers prospects as low cost, slow release soil conditioner and fertiliser for a long term effect.
\end{abstract}

Keywords: agricultural waste, manure, biochar, slow release fertilizer, pyrolysis, Phaseolus vulgaris, Eisenia fetida

\section{Introduction}

Nowadays handling of pig manure due to their increased amounts together with a stricter environmental regulation increases the search for economic viable and environmental friendly treatments. The storage of pig manure has an impact on the quality of air, groundwater and surface water. Manure also results in the release of $\mathrm{NH}_{3}, \mathrm{~N}_{2} \mathrm{O}$ and volatile organic compounds and has an odour nuisance (European Environment Agency [EEA], 2009). Many techniques such as anaerobic and aerobic digestion, composting and flocculation have been studied for the treatment of pig manure. These techniques have some drawbacks, and in some cases contribute to pollution of the environment. A very interesting alternative is a thermochemical conversion using pyrolysis. The first results of this treatment described in literature are promising, although pyrolysis of pig manure has not been thoroughly investigated yet (Cantrell, Hunt, Uchimiya, Novak, \& Ro, 2012); (Xiu, Shahbazi, Shirley, \& Cheng, 2010). Pyrolysis as thermochemical conversion method for pig manure entails different benefits such as: a shorter conversion time compared to composting, the absence of non-biodegradable and toxic substances destroying pathogens that can be found in manure and of course the conversion to value-added products (Ro, Cantrell, \& Hunt, 2010).

The thermal conversion of biomass residues and waste streams in absence of oxygen into products with added value is a well-known process. These streams can be converted at relatively low temperatures via pyrolysis into three fractions: biochar, bio-oil and bio-gas. Each pyrolysis product has its own valorisation route and products with unique properties (Demirbas, 2001); (Tuck, Perez, Horvath, Sheldon, \& Poliakoff, 2012). The biochar can be used as an alternative for fertilizers as it contains not only $\mathrm{C}$, but also relative high amounts of $\mathrm{N}, \mathrm{P}$ and $\mathrm{K}$ or as precursor for the production of activated carbon (AC) (Azargohar \& Dalai, 2006); (Dias, Alvim-Ferraz, Almeida, Rivera-Utrilla, \& Sanchez-Polo, 2007). Many studies have reported beneficial effects of biochar as a soil amendment for improving soil quality and crop productivity (Schulz \& Glaser, 2012); (Zhang et al., 2010). Amendment biochar can restore soil fertility and could be used to replenish soil carbon pools and sequester $\mathrm{CO}_{2}$ as a double win option. These biochar management systems can be seen as modern analogues of this Amazonian 
phenomenon, terra preta de Indio, where aboriginal cultures boosted soil productivity of highly weathered tropical soils mainly through the incorporation of biochar and nutrients into the soil.

A further advantage is that biomass waste streams, present on a large scale around the world, have a low economic value, and do not contribute significantly to the final price of the products obtained. Pyrolysis of biomass waste streams leads to sustainable, environmentally friendly and economically attractive products with added value. Manure processing via pyrolysis is rather limited focused on the bio-oil and biochar. However, the latter can be used, because of its composition, as an alternative for chemical fertilizers (Cantrell et al., 2012); (Uchimiya, Bannon, Wartelle, Lima, \& Klasson, 2012). Recently production of AC from biochar as an effective valorisation route is also investigated (Galinato, Yoder, \& Granatstein, 2011); (Tuck et al., 2012). The low economic value of the manure together with low production cost and the advantages of the biochar makes it a very interesting economical pathway (Kuppens, Van Dael, Maggen, et al., 2014); (Kuppens, Van Dael, Vanreppelen, et al., 2014).

This study will prove that implementing amendment biochar from pig manure to a soil has a positive effect on soil properties and on cultivating beans.

\section{Materials and Methods}

\subsection{Materials and Soil Preparation}

The dry, solid fraction of pig manure was obtained as pellets with a dry-matter content of $32 \mathrm{wt} . \%$. and dried overnight $\left(110^{\circ} \mathrm{C}\right)$ to increase the dry-matter content. After drying, the pellets were ground $(<2 \mathrm{~mm})$ for further pyrolysis and analysis. The manure was sent to Schwerin (Germany) were a pilot pyrolysis installation from Renovia enterprise was used to obtain high amounts of biochar. Renovia enterprise is a company that is investing in the valorisation of manure and other biomasses via pyrolysis and fermentation. The installation was equipped with an automated feeder and uses a unique patented heating system consisting of a horizontal reactor tube with a double hollow screw system filled with a liquid salt and working at an operating temperature of $450^{\circ} \mathrm{C}$. The residence time of the manure is about $1 \mathrm{~h}$.

This biochar is evaluated as a soil improver mixed with a sandy ( $88 \%$ sand, $8 \%$ silt and $4 \%$ clay) contaminated soil from a testing field in Lommel (Belgium) which is located $500 \mathrm{~m}$ from a metal processing plant (smelter). This soil is chosen due to multiple studies in upgrading this soil suffering from historical contamination (Bouwman \& Vangronsveld, 2004). The soil was first air-dried and sieved to remove stones and plant residues. Afterwards, the biochar was added to create the blended soils. Sandy soils were blended with 2, 5 and 10 weight percentage (wt.\%) of biochar from pyrolysed swine manure and mixed for 5 minutes. Tests and analysis were performed after the soil was conditioned for three months.

\subsection{Chemical Analysis of Swine Manure and Derived Biochar}

For the thermogravimetric analysis (TGA) of overnight dried samples a DuPont 951 TGA instrument device was used to determine moisture, volatile matter, fixed carbon and ash content. The standard ASTM methods for the analysis of chars were applied (International, 2011). Elemental analysis of carbon (C), nitrogen (N), hydrogen $(\mathrm{H})$, sulphur $(\mathrm{S})$ and oxygen $(\mathrm{O})$ was carried out with a Thermo Electron Flash EA1113 element analyser with BBOT (2, 5-bis(5-tert-butyl-benzoxazol-2-yl) thiophene with formula $\mathrm{C}_{26} \mathrm{H}_{26} \mathrm{~N}_{2} \mathrm{O}_{2} \mathrm{~S}$ ) as standard for calibration. Concentration of metals and non-metals were determined by inductively coupled plasma atomic emission spectrometry (ICP-AES) after microwave digestion. Since there are no specific standard procedures described or developed for the decomposition of manure, several standard procedures were tested. The best procedure applied was the standard "microwave digestion of plants in a closed vessel" and uses $5 \mathrm{ml}$ of concentrated nitric acid $\left(\mathrm{HNO}_{3}\right.$, suprapur) and $3 \mathrm{ml}$ of hydrogen peroxide $\left(\mathrm{H}_{2} \mathrm{O}_{2}, 30 \%\right)$ followed by a single step microwave treatment (Table 1) (Milestone MLS 1200-Mega) (Araujo, Gonzalez, Ferreira, Nogueira, \& Nobrega, 2002). The char produced from pyrolysis was digested in two steps rather than in one step as described above for the pig manure. In a first step, $3 \mathrm{ml} \mathrm{HNO}_{3}$ suprapur and $2 \mathrm{ml} \mathrm{H}_{2} \mathrm{O}_{2} 30 \%$ were used. In the second step, $2 \mathrm{ml} \mathrm{HNO}_{3}$ supra pure and $1 \mathrm{ml} \mathrm{H}_{2} \mathrm{O}_{2} 30 \%$ were added again. Finally, the obtained solutions were filtered and diluted with Milli-Q water in a volumetric flask. The determination of element concentrations in the solution was done using a Perkin Elmer Optima 3000 DV ICP-AES device with an axial plasma configuration. 
Table 1. Microwave program for the digestion of manure and biochar

\begin{tabular}{|c||cc|}
\hline Step 1 & Time (min) & Power (W) \\
& 2 & 200 \\
& 1 & 0 \\
& 5 & 200 \\
& 5 & 340 \\
& 5 & 400 \\
& 20 & 340 \\
\hline Step 2 & 5 & 200 \\
& 5 & 340 \\
& 5 & 400 \\
& 5 & 500 \\
& 15 & 340 \\
\hline
\end{tabular}

To use amendment biochar as a natural soil improver and fertilizer, the impact of the leachability of the metals and the nutrients is a key parameter. Leachability will indeed provide insight on the mobility of the major nutrients $(\mathrm{N}, \mathrm{K}$ and $\mathrm{P})$ and a number of heavy metals present. It is favourable that nutrients are released slowly while the metals remain in the biochar. Therefore, Milli-Q water or a solution of $\mathrm{CaCl}_{2}, \mathrm{HNO}_{3}, \mathrm{KCl}$ or $\mathrm{NH}_{4} \mathrm{OAc}$, respectively, was added to the char as described by Faridullah et al. (2012). The solution was filtered through a 0.45 micron Millipore filter and analysed with ICP-AES. This extraction was also executed dynamically for the Milli-Q and $\mathrm{KCl}$ solutions: the solution was replaced every 24 hours by a "fresh" solution to estimate how much material could be leached within a certain period of time and to determine its maximum limit of leaching. This 24 hours' cycle was repeated 4 times. A first outcome on a one step leaching can be formed via conductivity measurements. Each solution is selected to examine the change in conductivity at a different level. The change in conductivity for Milli-Q water is based on the solubility of metals present. For $\mathrm{HNO}_{3}$ this change is based on acid-base reactions. The change in conductivity using $\mathrm{Ca}\left(\mathrm{NO}_{3}\right)_{2}$ and $\mathrm{CaCl}_{2}$ is based on exchangeable ions while with $\mathrm{KCl}$ as indifferent electrolyte the change is based on ionic strength.

Fourier Transform Infrared Spectroscopy (FTIR) was carried out for the initial biomass and char to characterize the bulk composition using a Bruker Vertex 70 FTIR spectrometer equipped with a DTGS detector. The dried samples are pressed into a $\mathrm{KBr}$ pellet. The spectrum was recorded in transmission between 4000 to $480 \mathrm{~cm}^{-1}$ (number of scans: 32, resolution: $4 \mathrm{~cm}^{-1}$ ).

\subsection{Physicochemical Analysis of Biochar Blended Soils}

The acidity of the char gives an idea about the mobility of metals in the soil and plant growth. Therefore, Milli-Q water was added to the blended soil (Carter, 1993). This procedure was also used to determine the $\mathrm{pH}$ of the soils. This is also done after cultivating. Metal concentrations were determined by wet digestion of the blended soils followed by ICP-AES as described in $\S 2.3$. $\mathrm{Ca}\left(\mathrm{NO}_{3}\right)_{2}$ was used for the determination of the exchangeable metals in soil. Using this method, phyto-toxic heavy metals for plants are exchanged with Ca-ions. In addition to the metal concentration, different key parameters such as $\mathrm{pH}$, organic matter, chemical bonding of the metals and intrinsic plant parameters have to be taken into account, all of which have an effect on the availability and therefore the uptake of metals by the plant (Gleyzes, Tellier, \& Astruc, 2002).

The Cation Exchange Capacity (CEC) a good indicator of soil quality and productivity (Extension \& United States. Cooperative State Research, 1995). It measures the quantity of negatively charged positions on soil surfaces. The Water Holding Capacity (WHC) is a parameter for determining the amount of water that soil can hold relative to its dry mass. The WHC can be calculated from the equation:

$$
\text { WHC (as a percentage of the dry weight) }=\frac{(S-T-D)}{D} \times 100
$$

Here $\mathrm{S}$ is the mass of the tube, the filter paper and the water-saturated blended soil; $\mathrm{T}$ is the mass of the tube and the filter paper; D is the mass of the dried blended soil (Standardization, 2012).

In order to evaluate salt stress on worms (Eisenia fetida) an extra washing step procedure with deionized water 
was needed based on preliminary worm test experiments. The soil was mixed with distilled water in a $1 / 2(\mathrm{~g} / \mathrm{v})$ ratio. The slurry was stirred for 1 minute and kept aside for 15 minutes; this procedure was repeated 4 times. The slurry was left to settle for $24 \mathrm{~h}$ before decantation. Samples of the washing water were analysed using ICP-AES, conductivity and $\mathrm{pH}$ measurements. The remaining wet soil was left 4 weeks to dry at ambient temperature.

\subsection{Plant Grow Tests with Beans}

The dwarf beans (Phaseolus vulgaris), also called "Limburgse vroege", were sown on the stabilized soils blended with amendment biochar and on a soil without this biochar for control. The soils with beans were placed in a specially designed growth chamber which mimics natural conditions. (Vanassche \& Clijsters, 1990). The plants were carefully removed from the soil after the growth period of 15 days. The roots were washed gently to remove the grains of biochar and soil. The plant is then separated into 3 parts: the leaves, roots and stem according reference (Vanassche \& Clijsters, 1990). The analysis of the bean plant takes place in three steps. First, all parts of plants are weighted separately. Further, the length of the stem is also measured. Second, the enzymatic activity is examined for every plant. Samples are stored in a freezer at $-80{ }^{\circ} \mathrm{C}$ prior to analysis. Thirdly, the metal concentration in the leaves of every plant is determined using $200 \mathrm{mg}$ of dried leaves digested in pure, warm nitric acid $\left(\mathrm{HNO}_{3}\right)$. After digestion suprapur $\mathrm{HCl}$ and Milli-Q water was added. The metal concentrations in these solutions are determined by ICP-AES (Vanassche \& Clijsters, 1990). The roots are not used for the analysis of metal concentrations due to remains of soil that cannot be washed off.

\subsection{Soil Toxicity Tests with Worms}

The worms (Eisenia fetida) were obtained from synchronized cultures and fed with cow manure. The untreated Lommel soil was chosen as reference. Tap water was added to these containers and humidity was monitored during the test and adjusted if necessary (Standardization, 2012). Survival, growth (biomass) and number of cocoons were used as endpoint. Small bait portions consisting of oatmeal and activated carbon were fixed in holes pierced in PVC strips (Bait lamina). These strips with ten holes each were placed in the soils of the containers mentioned above. The worms added to the soils progressively feed on the bait placed in the soil substrate. The disappearance of the bait material after one week was directly associated with the feeding activity of the worms (Kratz, 1998). Analysis is done by weighing the worms before and after the soil toxicity test. The worms and their produced cocoons are also counted after 4 weeks for a first indication of the toxicity of the soils. The number of open holes in the PVC strips is counted and expressed in percentage for comparison. All the results are then statistically analysed (Kruskal-Wallis, Mann-Whitney U) to see if there is a significant difference between the soils blended with amendment biochar and the reference. The independent samples Kruskal-Wallis test was used to check if there is a significance for the cocoons, mortality, growth and bait lamina not taking into account the different blends. The Mann-Whitney $U$ test was used to check if there are significant differences between the 0,2 and $5 \mathrm{wt} . \%$ soils within the cocoons, mortality, growth and bait lamina. If the significance is less than 0.05 the difference is regarded as significant (Solutions)

\section{Results and Discussion}

\subsection{Characterization of the Manure and Biochar}

The major part $( \pm 77$ wt.\%) of the manure consists of volatile matter $(45 \%)$ and ash $(32 \%)$. The rest of the manure consists of fixed carbon $( \pm 18 \mathrm{wt} . \%)$ and moisture $( \pm 4 \mathrm{wt} . \%)$. The composition of the biochar shows significant differences as a result of pyrolysis. A temperature of up to $450^{\circ} \mathrm{C}$ is reached during the pyrolysis process, causing the volatile matter to drop under $5 \mathrm{wt} \%$ increasing simultaneously the amounts of ash and fixed carbon. The amount of fixed carbon doubled to about $43 \mathrm{wt} . \%$ and the ash content shows an increase of $66 \%$ to about $52 \mathrm{wt} . \%$. These results are summarized in Table 2.

Table 2. Thermogravimetric and elemental analysis of the manure and biochar

\begin{tabular}{|c|ccccccccc|}
\hline Sample & $\mathrm{W}^{\mathrm{ad}}$ & $\mathrm{Ash}^{\mathrm{db}}$ & $\mathrm{VM}^{\mathrm{db}}$ & $\mathrm{C}_{\mathrm{fix}}^{\mathrm{db}}$ & $\mathrm{C}$ & $\mathrm{H}$ & $\mathrm{N}$ & $\mathrm{S}$ & $\mathrm{O}^{\text {diff }}$ \\
\hline Virgin Manure & 4.1 & 32.4 & 45.4 & 18.1 & 30.1 & 4.0 & 2.7 & 0.5 & 30.3 \\
\hline Amendment Biochar & 1.4 & 51.6 & 4.4 & 42.8 & 33.0 & 1.1 & 1.8 & 0.1 & 12.4 \\
\hline
\end{tabular}

${ }^{\mathrm{db}} \mathrm{dry}$ basis; ${ }^{\text {ad }}$ air dried, $\mathrm{O}^{\text {diff }}=100-(\mathrm{C}+\mathrm{H}+\mathrm{N}+\mathrm{S}+\mathrm{Ash}), \mathrm{db}$

Element analyses are also shown in Table 2. The biggest difference between the virgin manure and amendment biochar can be found in the $\mathrm{O}$ content. The virgin manure has an $\mathrm{O}$ content of $30.3 \mathrm{wt} . \%$ while the amendment biochar has only 12.4 wt.\% of $\mathrm{O}$ content. This decrease in $\mathrm{O}$ content can be explained by the conversion of 
compounds in the virgin manure resulting in volatile matter $\left(\mathrm{NO}_{\mathrm{x}}, \mathrm{SO}_{\mathrm{x}}, \mathrm{H}_{2} \mathrm{O}, \ldots\right)$ leaving the material and thus, beside a decrease in $\mathrm{O}$, also a decreasing $\mathrm{N}$ and $\mathrm{S}$ content.

The results of the ICP-AES analyses indicate a broad distribution of metal concentrations in the virgin manure (Table 3). High concentrations (> $20 \mathrm{mg} \cdot \mathrm{g}^{-1}$ ) of $\mathrm{Ca}, \mathrm{K}$ and $\mathrm{Mg}$ are present. $\mathrm{Na}$ and $\mathrm{P}$ are present in moderate concentrations $\left(>10 \mathrm{mg} \cdot \mathrm{g}^{-1}\right)$ while $\mathrm{Al}, \mathrm{Cu}, \mathrm{Fe}, \mathrm{Mn}$ and $\mathrm{Zn}$ are present in low concentrations $\left(<3 \mathrm{mg} \cdot \mathrm{g}^{-1}\right)$. Other (heavy) metals were not detected. Since most metals are not volatilized during pyrolysis under the given conditions, they are not found back in the bio-oil or gas. (Tack, Van Ranst, Lievens, \& Vandenberghe, 2006) This leads to a concentration increase in the biochar as visualised in Table 3. Elements present in the biochar are doubled in concentration compared with the starting material.

Table 3. Elemental composition of the virgin manure and amendment biochar

\begin{tabular}{|c|c|c|c|}
\hline \multirow{2}{*}{ Sample } & Ca & $\mathbf{K}$ & Mg \\
\hline & $\mathrm{mg}^{-\mathrm{g}^{-1}}$ & $\mathrm{mg} \mathrm{g}^{-1}$ & $\mathrm{mg}^{-\mathrm{g}^{-1}}$ \\
\hline Manure & $35.18(0.55)$ & $35.03(0.31)$ & $21.13(0.33)$ \\
\hline Biochar & $68.18(1.90)$ & $25.22(2.18)$ & $36.05(4.04)$ \\
\hline \multirow{2}{*}{ Sample } & $\mathrm{Na}$ & $\mathbf{P}$ & $\mathbf{F e}$ \\
\hline & $\mathrm{mg}^{-\mathrm{g}^{-1}}$ & $\mathrm{mg}^{-\mathrm{g}^{-1}}$ & $\mathrm{mg}^{-\mathrm{g}}$ \\
\hline Manure & $14.90(0.14)$ & $19.84(0.39)$ & $2.13(0.04)$ \\
\hline Biochar & $6.51(0.53)$ & $57.27(5.39)$ & $14.48(2.68)$ \\
\hline \multirow{2}{*}{ Sample } & Mn & Al & $\mathrm{Cu}$ \\
\hline & $\mathrm{mg} \cdot \mathrm{g}^{-1}$ & $\mathrm{mg} \mathrm{g}^{-1}$ & $\mathrm{mg} \mathrm{g}^{-1}$ \\
\hline Manure & $0.55(0.01)$ & $0.72(0.08)$ & $0.44(0.01)$ \\
\hline Biochar & $1.39(0.09)$ & $2.86(0.16)$ & $1.19(0.11)$ \\
\hline \multirow{2}{*}{ Sample } & Zn & $\mathrm{Cr}$ & $\mathbf{N i}$ \\
\hline & $\mathrm{mg}^{-\mathrm{g}^{-1}}$ & $\mathrm{mg}^{-1}$ & $\mathrm{mg} \mathrm{g}^{-1}$ \\
\hline Manure & $0.64(0.01)$ & $<0.01$ & $<0.1$ \\
\hline Biochar & $2.75(0.20)$ & & \\
\hline \multirow{2}{*}{ Sample } & $\mathbf{P b}$ & As & \\
\hline & $\mathrm{mg}^{-1}$ & $\mathrm{mg}^{-1}$ & \\
\hline $\begin{array}{l}\text { Manure } \\
\text { Biochar }\end{array}$ & $<0.1$ & $<\mathrm{DL}$ & \\
\hline
\end{tabular}

DL: below detection limit, standard deviation between brackets

FTIR spectra of the virgin manure and biochar are shown in Figures 1. The spectrum of the virgin manure clearly shows absorption bands of amides (3280, 1650, $1544 \mathrm{~cm}^{-1}$ ), carbonates (2500 (overtone), 1440, 873, and 714 $\mathrm{cm}^{-1}$ ), phosphates $\left(1080 \mathrm{~cm}^{-1}\right)$ and nitrates $\left(1385 \mathrm{~cm}^{-1}\right)$. The FTIR spectrum of the biochar shows clearly that the organic fraction in the biochar is almost completely carbonized by the absence of a significant response in the spectral range for $\mathrm{CH}$ absorptions $\left(2800-3000 \mathrm{~cm}^{-1}\right)$. Dominant IR absorption bands that are present can be related to the mineral fraction (carbonates, phosphates and nitrates). 


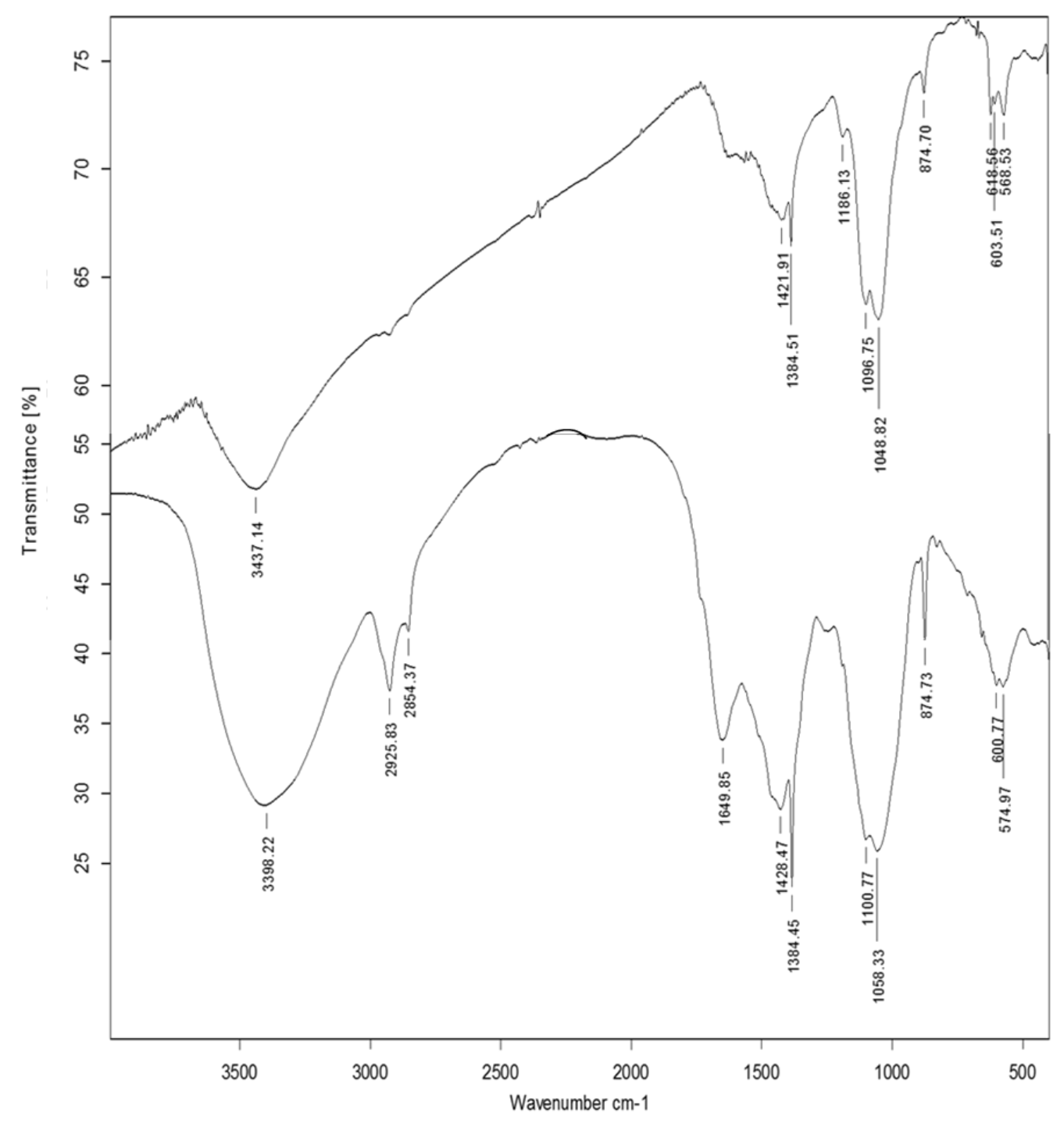

Figure 1. FTIR spectrum of the virgin manure (bottom) and fertilizer like biochar (top)

\subsection{Leachability of the Amendment Biochar}

The conductivity (Table 4) of the solution increased the most for the biochar mixed with $\mathrm{KCl}$ solution and Milli-Q water, the last because of its initial absence of ions and Milli-Q water is considered as a strong leaching agent. An increase in conductivity is also found for $\mathrm{CaCl}_{2}$ and $\mathrm{Ca}\left(\mathrm{NO}_{3}\right)_{2}$ stating that the $\mathrm{Ca}^{2+}$ presence will be exchanged with other ions present in the biochar. Table 4 also shows a sharp drop in conductivity for 0.1 and $0.5 \mathrm{M} \mathrm{HNO} \mathrm{H}_{3}$ solutions. This decrease in conductivity can be explained by the neutralisation reaction of the biochar. This neutralisation reaction by carbonate and phosphate explains the buffering action of the char. For $0.01 \mathrm{M} \mathrm{HNO} 3, \mathrm{NH}_{4} \mathrm{OAc}$ and $\mathrm{NH}_{4} \mathrm{OAc} / \mathrm{EDTA}$ treatments it can be stated that leaching of the biochar is rather limited. 
Table 4. Conductivity of the solution before and after immersion of amendment biochar for $24 \mathrm{~h}$

\begin{tabular}{|c|c|c|c|}
\hline & Milli-Q & $\mathrm{HNO}_{3}(0.5 \mathrm{M})$ & $\mathrm{HNO}_{3}(0.1 \mathrm{M})$ \\
\hline Conductivity of biochar $\left(\mathrm{mS} . \mathrm{cm}^{-1}\right)$ & $\begin{array}{l}3.23 \\
<001\end{array}$ & $\begin{array}{c}35.20 \\
148.50\end{array}$ & $\begin{array}{l}11.15 \\
3120\end{array}$ \\
\hline Difference & 3.23 & -113.30 & -20.05 \\
\hline & $\mathrm{HNO}_{3}(0.01 \mathrm{M})$ & $\mathrm{KCl}(1 \mathrm{M})$ & $\mathrm{Ca}\left(\mathrm{NO}_{3}\right)_{2}(0.1 \mathrm{M})$ \\
\hline $\begin{array}{l}\text { Conductivity of biochar }\left(\mathrm{mS} . \mathrm{cm}^{-1}\right) \\
\text { Conductivity control solution }\left(\mathrm{mS} . \mathrm{cm}^{-1}\right)\end{array}$ & $\begin{array}{l}4.40 \\
3.10\end{array}$ & $\begin{array}{l}96.17 \\
92.40\end{array}$ & $\begin{array}{l}18.07 \\
16.00\end{array}$ \\
\hline Difference & 1.30 & 3.77 & 2.07 \\
\hline & $\mathrm{CaCl}_{2}(0.1 \mathrm{M})$ & $\mathrm{NH}_{4} \mathrm{OAC}(1 \mathrm{M})$ & $\begin{array}{l}\mathrm{NH}_{4} \mathrm{OAC}(0.5 \mathrm{M}) \\
/ \operatorname{EDTA}(0.02 \mathrm{M})\end{array}$ \\
\hline Conductivity of biochar $\left(\mathrm{mS} . \mathrm{cm}^{-1}\right)$ & 5.28 & 57.30 & 35.05 \\
\hline Conductivity control solution $\left(\mathrm{mS} . \mathrm{cm}^{-1}\right)$ & 2.60 & 56.60 & 33.60 \\
\hline Difference & 2.68 & 0.70 & 1.45 \\
\hline
\end{tabular}

A better insight in the change in conductivity and leaching mechanisms can be obtained using dynamic leaching procedure. A $1 \times 96 \mathrm{~h}$ test is performed to see if saturation is reached between $24 \mathrm{~h}$ and $96 \mathrm{~h}$. The conductivity increase of the $1 \mathrm{M} \mathrm{KCl}$ solution shows a decrease after $48 \mathrm{~h}$ and remains constant the next 24 and $48 \mathrm{~h}$ at a somewhat lower value compared to the first $24 \mathrm{~h}$ leaching while the increase in conductivity in Milli-Q water decreases with each $24 \mathrm{~h}$ fresh leaching treatment (Figure 2). This can be interpreted as a limited leachability of the biochar in Milli-Q water in contrast to $\mathrm{KCl}$ where the ionic strength will affect solubility and conductivity.

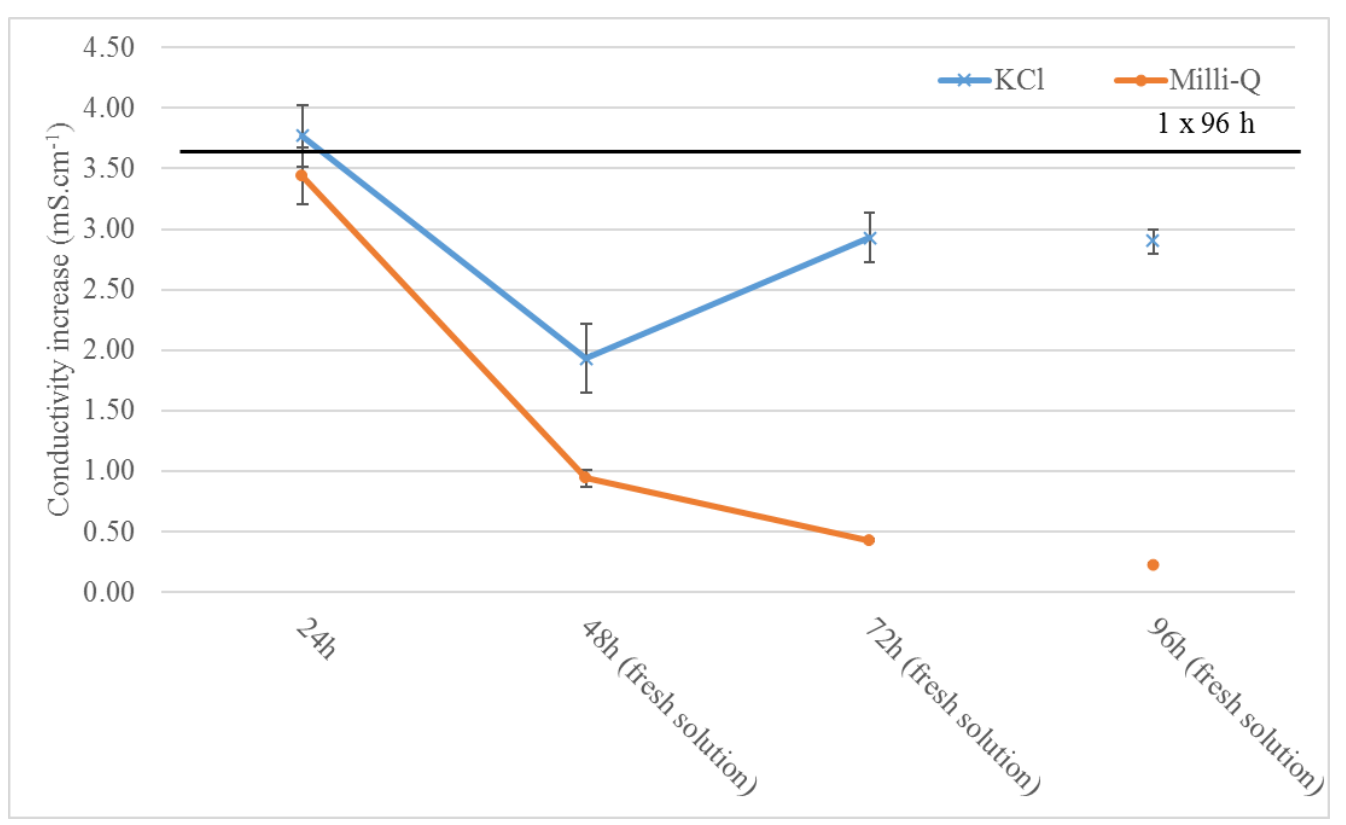

Figure 2. Conductivity increase in function of dynamic leaching of the amendment biochar in Milli-Q water and $\mathrm{KCl}$ solution $(1 \mathrm{M})$

Figure 3 shows the trend of the $\mathrm{pH}$ change as a function of the same dynamic leaching procedure. For the $1 \mathrm{M}$ $\mathrm{KCl}$ leaching an almost constant $\mathrm{pH}$ of 8.00 is reached for each fresh $\mathrm{KCl}$ treatment and this indepently for the $\mathrm{n}$ x $24 \mathrm{H}$ or 1 x $96 \mathrm{~h}$ application. For Milli-Q water $\mathrm{pH}$ increases steadily for each leaching treatment until almost the PZC of the amendment biochar is reached, being 9.4. For the $1 \mathrm{x} 96 \mathrm{~h}$ treatment this $\mathrm{pH}$ is not reached for Milli-Q water, a maximum of 8.4 can be noticed. The amendment biochar has the strong ability to buffer the 
solution due to the presence of carbonates and phosphates. As Milli-Q water is more aggressive this buffering effect is not perfectly compensated.

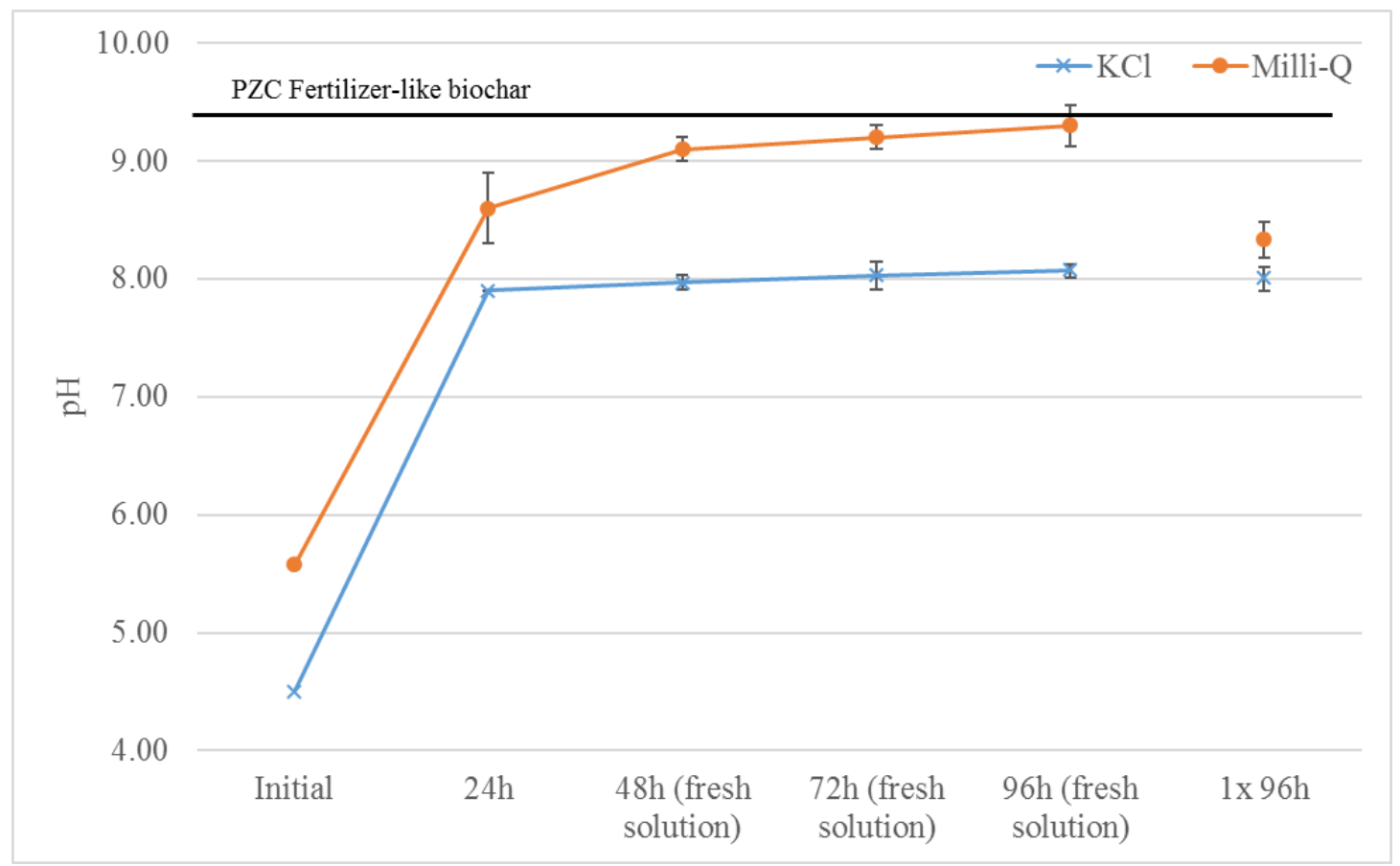

Figure 3. $\mathrm{pH}$ in function of dynamic leaching of the amendment biochar in Milli-Q water and $\mathrm{KCl}$ solution (1M)

Furthermore, we examined the ionic composition of the solutions after dynamic leaching of the amendment biochar. In the case of Milli-Q water (Figure 4), all analysed elements show a decreased concentration in function of leaching repeatability over a constant time. Figure 5 shows that $40 \%$ of $\mathrm{K}$ present in the biochar is leached after $96 \mathrm{~h}$. Ca and $\mathrm{Mg}$ with $3 \%$ and $2 \%$ removal are less leached in contrast to Na with $22 \%$ removal. Only $0.26 \%$ of $\mathrm{P}$ present in the biochar is leached, which is important in view of its plant availability suggesting a less soluble $\mathrm{P}$ species stronger bound in the biochar. This is an indication that $\mathrm{P}$ is present as calcium phosphate $\left(\mathrm{Ca}_{3}\left(\mathrm{PO}_{4}\right)_{2}\right)$ and that most of the released $\mathrm{Ca}$ is coming from calcium carbonate $\left(\mathrm{CaCO}_{3}\right) . \mathrm{Al}, \mathrm{Cu}, \mathrm{Zn}$ and Fe were not detected in the leaching solutions. Also this is an important fact in view of its environmental friendly and save use as soil amendment. The outcome is rather different for leaching with $\mathrm{KCl}$ (Figure 5) where the leaching is more or less constant in function of leaching repeatability over a constant time. $\mathrm{K}$ is not taken into account because of the matrix ( $\mathrm{KCl}$ solution). $48 \%$ of $\mathrm{Na}$ present in the biochar is leached after $96 \mathrm{~h} . \mathrm{Ca}, \mathrm{Mg}$ and $\mathrm{P}$ are leached for respectively $2 \%, 7 \%$ and $4 \%$ of the amount present in the biochar. $\mathrm{Al}, \mathrm{Cu}, \mathrm{Zn}$ and $\mathrm{Fe}$ were not detected in the leaching solutions. 


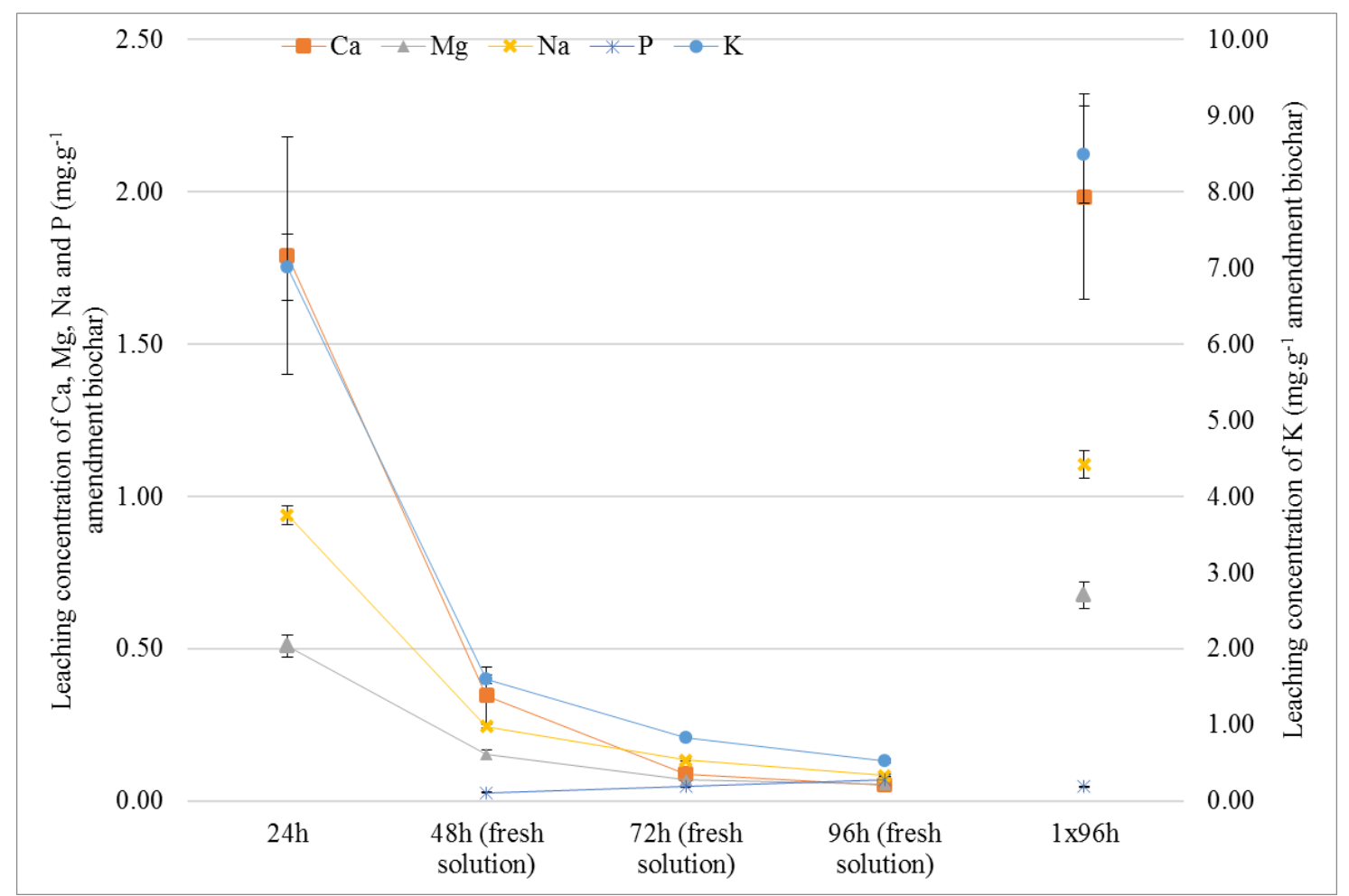

Figure 4. Elemental analysis of solution after dynamic leaching of the amendment biochar with Milli-Q water

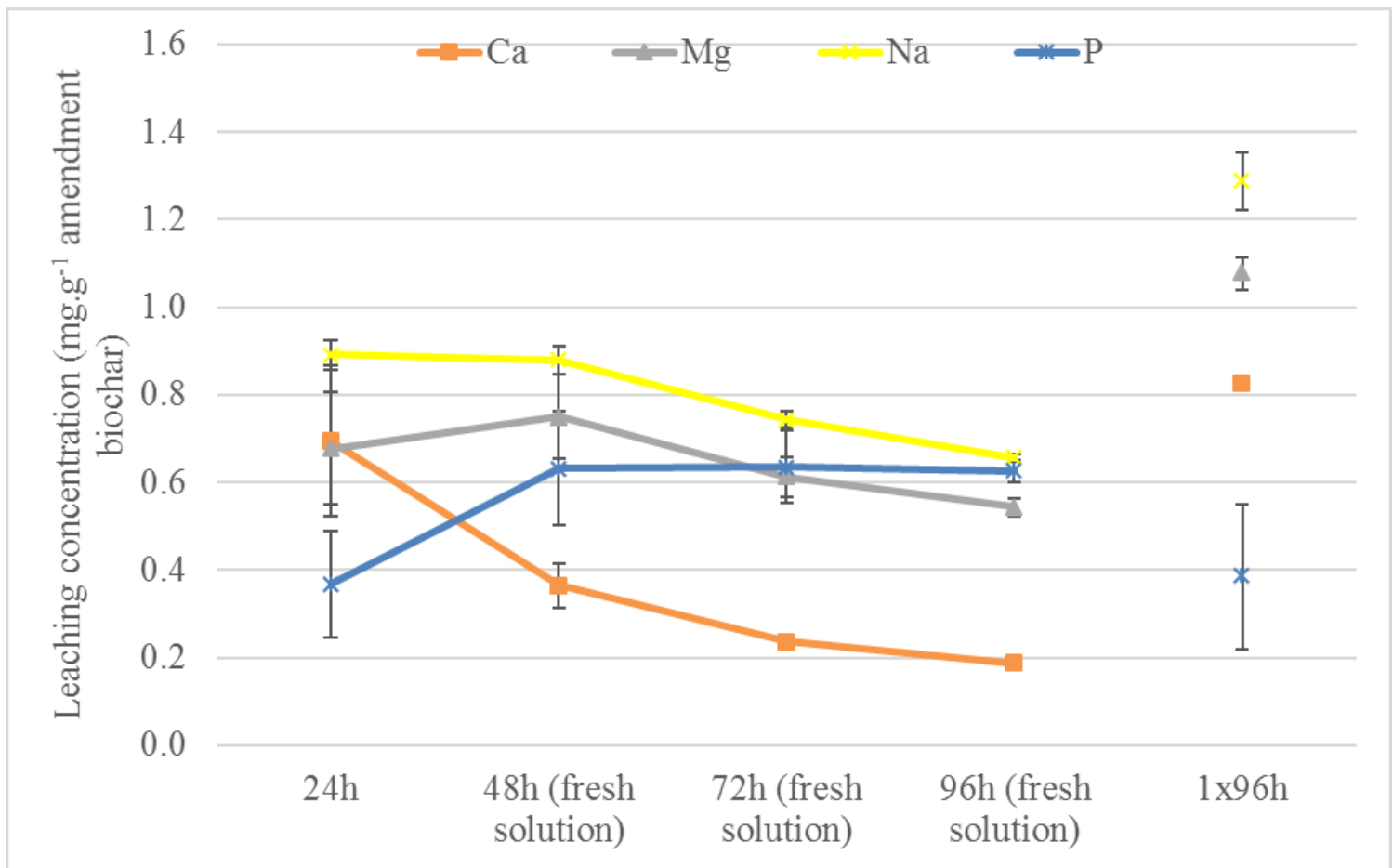

Figure 5. Elemental analysis of the solution after dynamic leaching of the amendment biochar with $\mathrm{KCl}$ solution (1M) 


\subsection{Characterization of the Amendment Biochar Blended Soils}

\subsubsection{Characterization of the Amendment Biochar Blended Soils}

Only the $2 \mathrm{wt} . \%$ and $5 \mathrm{wt} . \%$, besides the virgin sandy soil, are researched in more detail because of the positive plant growth. For the 10 wt.\% blending very negative plant growth results were obtained. The element concentrations of $\mathrm{K}, \mathrm{Al}, \mathrm{Cu}, \mathrm{Zn}, \mathrm{Mg}, \mathrm{Na}, \mathrm{Fe}$, and $\mathrm{P}$ in the soils are presented in Figure 6. This graph shows that the concentration of the elements increases with increasing content of biochar except for $\mathrm{Al}$ and $\mathrm{Fe}$, because of their high amounts already present in the virgin sandy soil and the relative small amount added via the amendment biochar. The $\mathrm{pH}$ values for the soils are $6.3,7.0$ and 7.3 for $0 \mathrm{wt} . \%, 2 \mathrm{wt} . \%$ and $5 \mathrm{wt} . \%$ respectively (Table 5). This increase in $\mathrm{pH}$ can be explained by its high PZC and the buffering capacity of the amendment biochar due to the carbonates and phosphates present in the biochar.

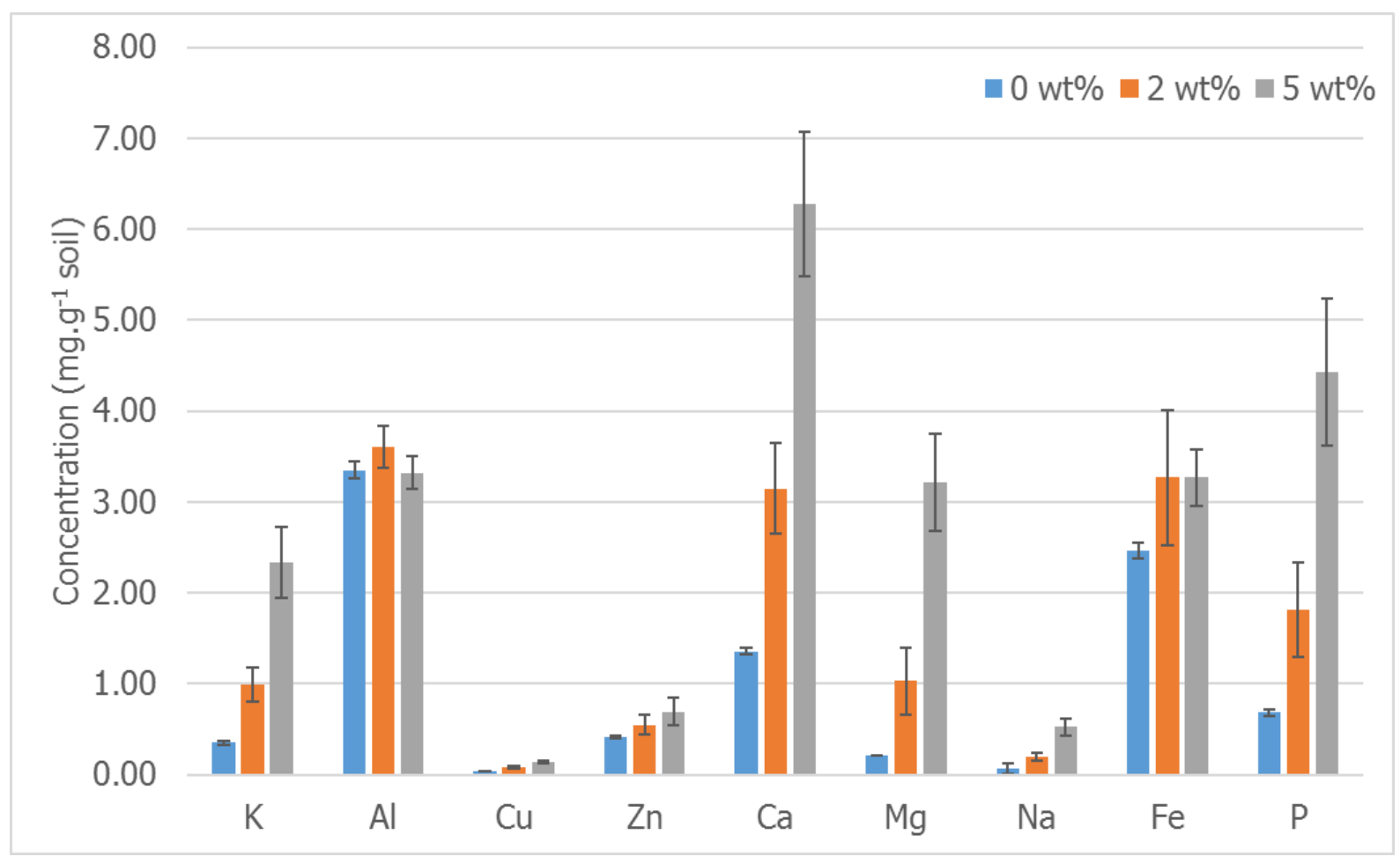

Figure 6. Elemental analysis of the soils with different wt.\% of amendment biochar

Table 5. pH, Water Holding Capacity, Cation Exchange Capacity and conductivity of the biochar blended soils (not washed)

\begin{tabular}{|c|cccc|}
\hline Sample & pH (before) & WHC $(\%)$ & CEC $\left(\mathrm{cmol}^{\mathrm{kg}}{ }^{-1}\right)$ & Conductivity $\left(\mu \mathrm{S} . \mathrm{cm}^{-1}\right)$ \\
\hline 0 wt\% biochar & 6.3 & 42.8 & 5.9 & 143.7 \\
2 wt\% biochar & 7.0 & 54.0 & 7.3 & 422.3 \\
$\mathbf{5}$ wt\% biochar & 7.3 & 57.2 & 8.2 & 1088.7 \\
\hline
\end{tabular}

The WHC increases with increasing biochar content from about $43 \%$ for the soils without biochar till about $57 \%$ for the soils with $5 \mathrm{wt} . \%$ biochar (Table 5). The difference between $2 \mathrm{wt} . \%$ and $5 \mathrm{wt} . \%$ is rather small. This shows that soils containing biochar can retain more water than those without which is ideal for sandy soils that dry out easily. The same trend is found for the CEC (Table 5) which increases with increasing content of biochar and can be related with the adsorptive character of the biochar. The more biochar in the soil the more it tends to retain positively charged ions in the soil. The difference between $2 \mathrm{wt} . \%$ and $5 \mathrm{wt} . \%$ amendment biochar is however more expressed. The CEC rises with almost $24 \%$ when $2 \mathrm{wt} . \%$ amendment biochar is added to the soil and with an additional $12 \%$ when $5 \%$ is added.

In contrast to the conductivity, it increased dramatically by adding the amendment biochar. This is the reason why a washing step of the $2 \mathrm{wt} . \%$ and $5 \mathrm{wt} . \%$ blended soils is executed for the worm experiments. Indeed, it was 
found that in case of the worm experiments, the conditions for reproduction and bait lamina test were rather negative.

\subsubsection{Effect of Cultivation on Biochar Amendment Soil}

The results can be found in Figure 7 for all plant parts showing that plant uptake of these elements increases with increasing biochar content. K, Ca, Mg and P concentrations increase very strongly for the $2 \mathrm{wt} . \%$ blend and even with the same tendency, except perhaps for Fe, for the $5 \mathrm{wt} . \%$ blend while the increase for the other elements is rather moderate. The change in exchangeable dedicated elements is also checked. These results can be found in Figure 8 in terms of leachable elements without and with cultivation. The range for the 0 wt. \% blended soil is between 0 and $0.07 \mathrm{mg} / \mathrm{g}$ soil, for the $2 \mathrm{wt} . \%$ blended soil it is between 0 and $0.35 \mathrm{mg} / \mathrm{g}$ soil, while for the $5 \mathrm{wt} . \%$ blended soil it has a range between 0 and $0.56 \mathrm{mg} / \mathrm{g}$ soil. What stand out is that the range of the increases with increase percentage of biochar. This observation coincides with the increasing cation exchange capacity as discussed in §3.3.1. For the soil without biochar the leachability before and after planting changed only slightly in favour of the cultivated soil for $\mathrm{K}, \mathrm{Zn}, \mathrm{Mg}$ and $\mathrm{Na}$; for $\mathrm{P}$ the change is negligible. The soils with $2 \mathrm{wt} . \%$ and 5 wt.\% biochar show that $\mathrm{K}, \mathrm{Mg}$ and $\mathrm{P}$ are released more after harvesting. However, $\mathrm{Zn}$ is less released than before planting. The released amounts of $\mathrm{Al}, \mathrm{Cu}$ and $\mathrm{Fe}$ are below $0.01 \mathrm{mg} / \mathrm{g}$. Ca cannot be measured due to the use of $\mathrm{Ca}\left(\mathrm{NO}_{3}\right)_{2}$ for the determination of exchangeable metals.

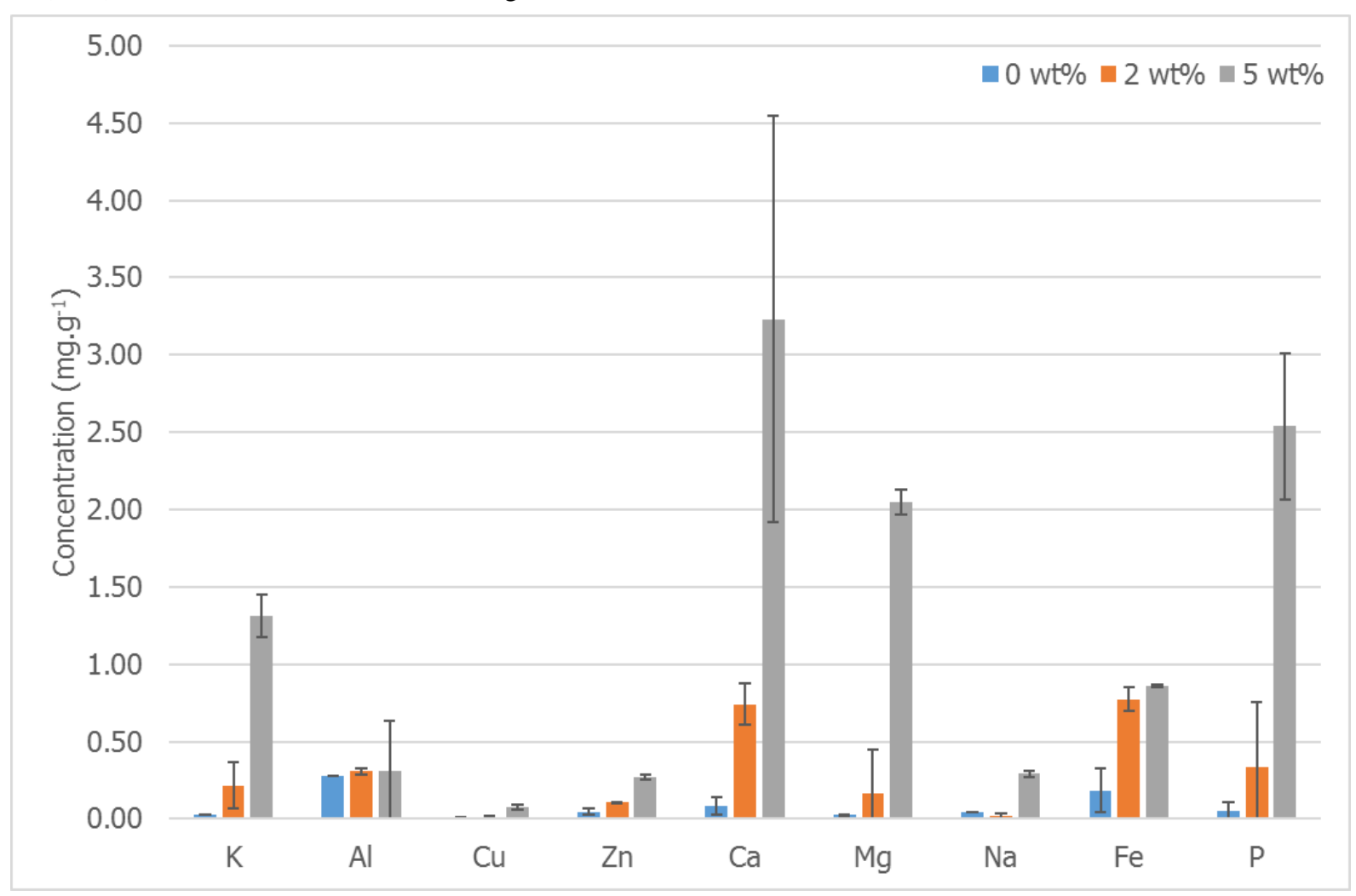

Figure 7. Analysis of the uptake of different elements by the plant 


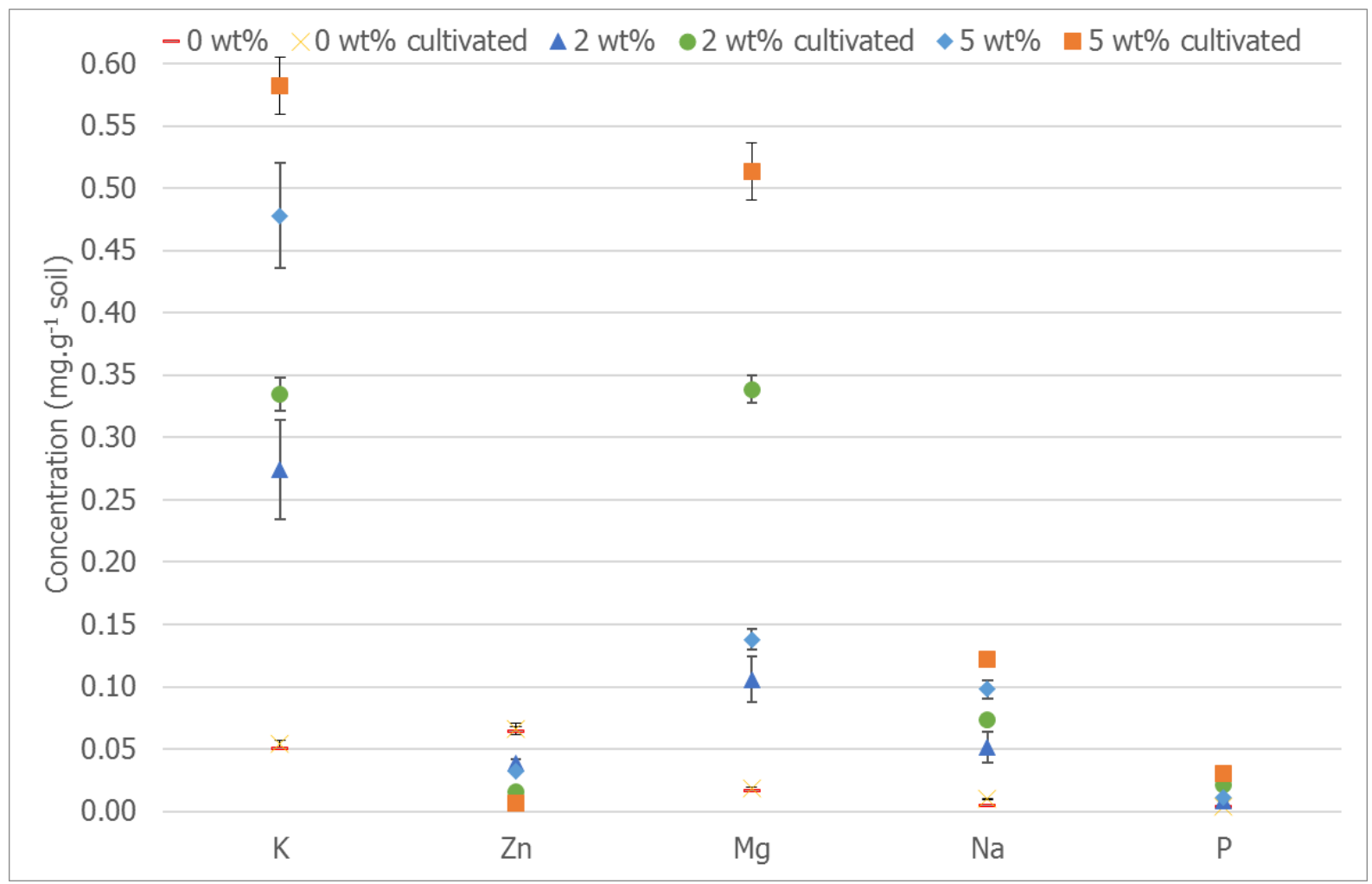

Figure 8. Elemental analysis of the leaching (24h) from 0, 2 and 5 wt.\% biochar blended soil before and after harvesting

There is no general trend for the conductivity (Figure 9) between the different soils. Conductivity increases after harvesting for the $0 \mathrm{wt} . \%$ en $2 \mathrm{wt} . \%$ blended soils stating that there are more soluble present due to the amendment biochar. However, for the $5 \mathrm{wt} . \%$ soils a drop in conductivity is found. The initial $\mathrm{pH}$ value for the soils (Figure 10) is between 6.3 and 7.3. The $\mathrm{pH}$ in the soils without amendment biochar drops $0.6 \mathrm{pH}$ units after harvesting in contrast to the soils with amendment biochar which drop only 0.2 and $0.1 \mathrm{pH}$ units for the $2 \mathrm{wt} . \%$ and $5 \mathrm{wt} . \%$ respectively. This confirms again the buffering capacity of the biochar in the soil.

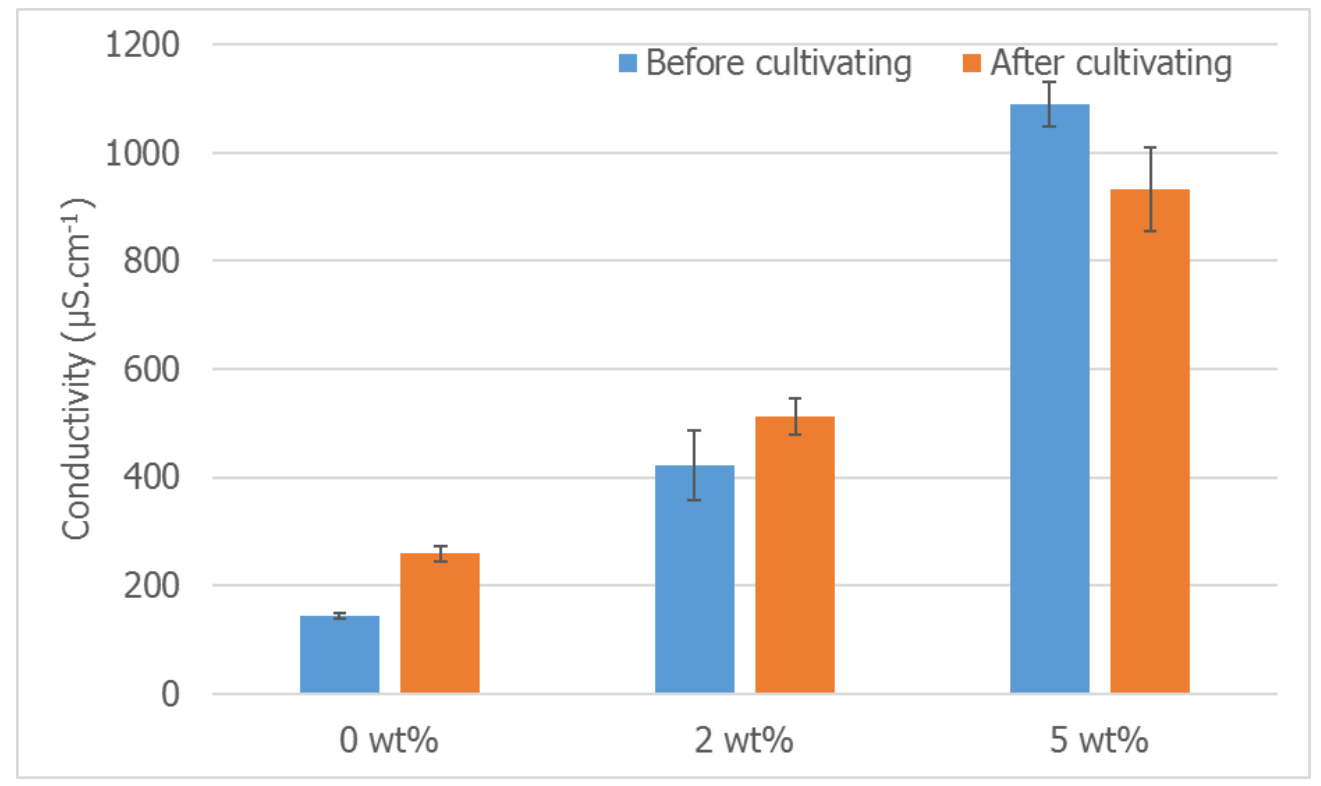

Figure 9. Conductivity before and after harvesting (24h) of the biochar blended soils 


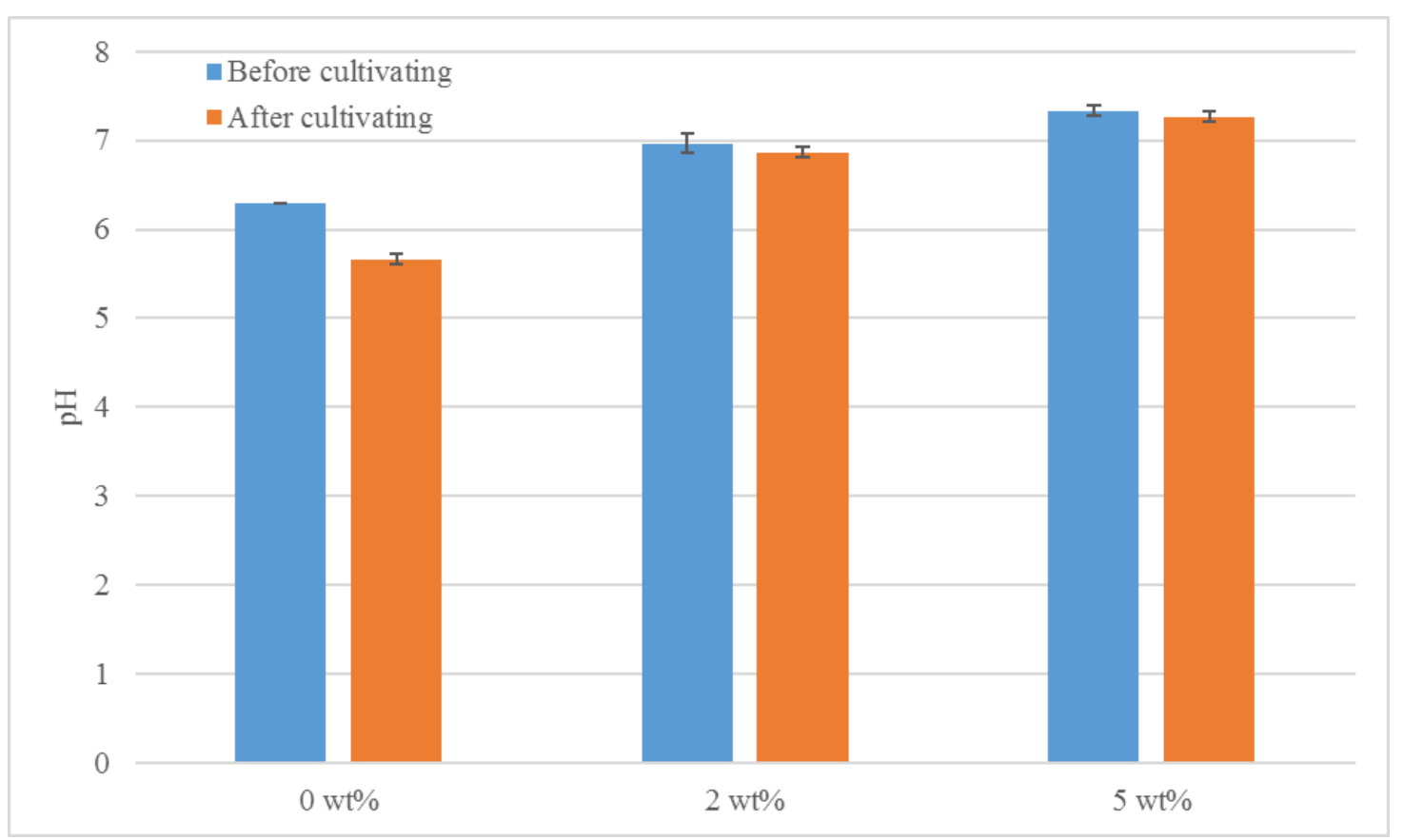

Figure 10. $\mathrm{pH}$ before and after harvesting of the biochar blended soils

\subsubsection{Effect of Char on Plant Properties}

The growth results of the plants after 2 weeks in the growth chamber can be seen in Table 6 . The effect on a soil with or without biochar is clearly demonstrated. Initially it was thought that a higher content of biochar would be beneficial for plant growth, but this test shows the opposite. Soils with $10 \mathrm{wt} \%$ biochar have a negative impact on plant growth. The explanation for this is that biochar tends to retain the water and thus higher biochar content increases the water holding capacity of the soil which becomes too wet and the bean plants become mouldy. Soils with $10 \mathrm{wt} . \%$ biochar are therefore not included in the further analyses. Minor visual differences between plants grown on soils with $2 \mathrm{wt} . \%$ and $5 \mathrm{wt} . \%$ biochar are observed and these plants grow 2 times faster than plants on soils without biochar. Length of the stems is measured and the leaves, roots and total plant are weighed for verification of the visual differences. These values are presented in Table 6 showing that plants grown on soils with $2 \mathrm{wt} . \%$ and $5 \mathrm{wt} . \%$ biochar are almost 2 times heavier compared to plants cultivated on the same soils without biochar. Additional it was found that crop yields were also much higher for the $2 \mathrm{wt} . \%$ biochar blending then in the case of the native soil but these results are not published yet.

The enzymatic activity in the root and the leaf is examined in order to have a better view on which soil is best for bean cultivation. The enzymatic activity can be considered as a measure of the stress induced in the plants. The higher the stress in the root and the leaf, the smaller the plant reflects an increased phytotoxicity in the soil. The results of the enzymatic activity in leaves and roots are also included in Table 6. From the enzymatic activity in the leaf, we see a significant decrease for a higher percentage of biochar in the soil. The enzymatic activity decreases by $50 \%$ for ME and ICDH, for GPOD this is even 75\%. The enzymatic activity in the roots behaves differently from the trends found in leafs. For example, the data show that a minimum is reached for soils with 2 wt.\% biochar while for the soils with $5 \mathrm{wt} . \%$ biochar the enzymatic activity decreases for ME and GPOD. The enzymatic activity also decreases by 50\% compared to the soils without biochar. One can conclude that no significant differences between the soils with $2 \mathrm{wt} . \%$ and $5 \mathrm{wt} . \%$ biochar were found. However, improved enzymatic activities for these blends were measured compared to the $0 \mathrm{wt} . \%$ soil. The $2 \mathrm{wt} . \%$ char is better for the roots enzymatic activity; the $5 \mathrm{wt} . \%$ char is better for the leaves enzymatic activity. Economically, the $2 \mathrm{wt} . \%$ blending is more interesting than the $5 \mathrm{wt} . \%$ due to the fact that with $2 \mathrm{wt} . \%$ more soil can be blended and the results are the same. 
Table 6. Plant growth and enzymatic activity of plants grown on biochar blended soils

\begin{tabular}{|c||c|c|c|}
\hline & 0 wt\% & 2 wt\% & 5 wt\% \\
\hline \hline Number of plants & 9 & 11 & 10 \\
\hline Plant mass (g) & $1.29(0.34)$ & $2.19(0.35)$ & $2.27(0.43)$ \\
\hline Leaf mass (g) & $0.75(0.27)$ & $1.44(0.28)$ & $1.52(0.25)$ \\
\hline Root mass (g) & $0.67(0.32)$ & $1.33(0.27)$ & $1.38(0.43)$ \\
\hline Length (cm) & $6.49(0.54)$ & $11.37(1.60)$ & $11.50(1.46)$ \\
\hline Enzymatic activity roots (mU.g $\left.{ }^{-1}\right)$ & & & \\
\hline ME & $77(7)$ & $42(8)$ & $48(8)$ \\
\hline GIDH & $-31(3)$ & $-18(3)$ & $-20(3)$ \\
\hline GPOD & $853(66)$ & $567(230)$ & $681(111)$ \\
\hline Enzymatic activity leafs (mU.g $\left.{ }^{-1}\right)$ & & & \\
\hline ME & $118(24)$ & $60(12)$ & $53(3)$ \\
\hline ICDH & $113(10)$ & $67(14)$ & $59(3)$ \\
\hline GPOD & $311(113)$ & $77(34)$ & $48(5)$ \\
\hline
\end{tabular}

Number of plants with respect to 12 beans planted, standard deviation between brackets

The elemental concentration of $\mathrm{K}, \mathrm{Al}, \mathrm{Cu}, \mathrm{Zn}, \mathrm{Ca}, \mathrm{Mg}, \mathrm{Na}, \mathrm{Fe}$ and $\mathrm{P}$ in the leaves is shown in Figure 11. The concentration of $\mathrm{K}, \mathrm{Mg}$ and $\mathrm{P}$ increases with increasing concentration of biochar. On other hand, Ca decreases with increasing concentration of biochar in the soils. The concentrations of $\mathrm{Zn}, \mathrm{Na}$ and $\mathrm{Fe}$ are below 0.01 and $\mathrm{Al}$ and $\mathrm{Cu}$ are not detected in the leaves of the plant.

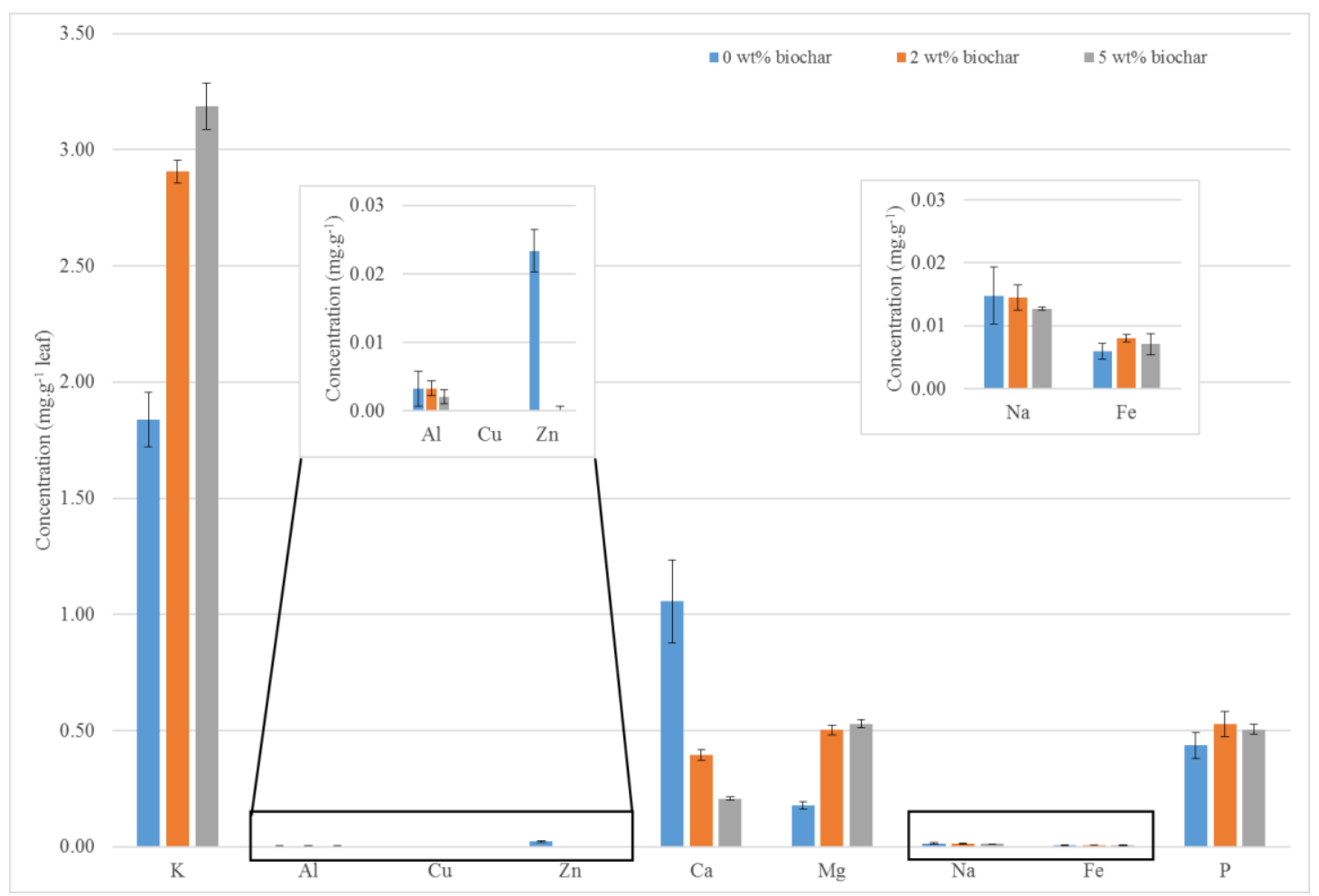

Figure 11. Elemental analysis of leaves from the plants grown on biochar blended soils

\subsubsection{Effect Soil on Worm Population/Reproduction}

The first test showed a significant lower growth in the soils with $5 \%$ and $10 \%$ biochar (both $\mathrm{p}=0.02$ ). Reproduction was significant lower in comparison with the original soil in all blended soils with biochar (resp. $0.02(2 \%), 0.01(5 \%)$ and $0.01(10 \%))$. The high values for conductivity indicate a potential impact of salt stress in biochar blended soils. Therefore, a washing step was included as described in $\S 2.1$. The results of this washing 
step can be found in Table 7. A strong reduction in conductivity with respectively $72 \%, 48 \%$ and $66 \%$ is noted for respectively $0 \mathrm{wt} \%, 2 \mathrm{wt} \%$ and $5 \mathrm{wt} \%$ biochar. A heavy rain fall will have the same effect, so no extra washing procedure have to be included when blending this kind of char with poor soils properly mixed. Nevertheless, the soil was washed according §1.2.1 and it was found that washing with tap water resulted in a higher and neutral $\mathrm{pH}$ of the blended soil. Also a slight increase in $\mathrm{pH}$ is found for the blended soils. This increase can be explained as the result of a buffering effect of the biochar. The raise in $\mathrm{pH}$ is most pronounced in the untreated Lommel soil. Soils blended with $2 \%$ and $5 \%$ biochar have a higher buffer capacity and show a reduced increase in soil pH in comparison to the untreated soil.

Table 7. Conductivity and $\mathrm{pH}$ before and after washing step

\begin{tabular}{|c|ccc|}
\hline & 0 wt\% biochar & 2 wt\% biochar & 5 wt\% biochar \\
\hline $\begin{array}{c}\text { Conductivity before } \\
\text { washing step } \\
\begin{array}{c}\text { Conductivity after } \\
\text { washing step }\end{array}\end{array}$ & $144 \mu \mathrm{S} . \mathrm{cm}^{-1}$ & $422 \mu \mathrm{S} . \mathrm{cm}^{-1}$ & $1089 \mu \mathrm{S} . \mathrm{cm}^{-1}$ \\
$\begin{array}{c}\text { pH before washing } \\
\text { step } \\
\text { pH after washing } \\
\text { step }\end{array}$ & $41 \mu \mathrm{S} . \mathrm{cm}^{-1}$ & $218 \mu \mathrm{S} . \mathrm{cm}^{-1}$ & $371 \mu \mathrm{S} . \mathrm{cm}^{-1}$ \\
\hline
\end{tabular}

The results of the reproduction and bait lamina test were collected and summarised in figure 12 and 13. Figure 12 shows the mass (before, after and increase) while figure 13 shows the number of cocoons (reproduction) of the worms (10 worms / container) and results of the bait lamina test. At first sight the results seem to be optimal for the soils with $2 \mathrm{wt} . \%$ biochar because of an increase in the numbers of cocoons and a higher \% of empty bait lamina. However, a statistical analysis is a much more objective evaluation. Therefore, an independent samples Kruskal-Wallis test is done with a significance of 0.05 . For the percent of mortality between the different samples no significant difference is found, which looks relevant. However, no significant difference between the percentages of empty bait lamina strips $(p>0.05)$ was found. The increase in weight of 0.095 has a significance which is still below 0.1 , but relevant. This difference will be considered significant by increasing $p$ to 0.1 , though, the probability will be larger than another replica will fall outside the confidence interval. By keeping the significance here at 0.05 , the difference here is not considered to be significant. Within the number of cocoons there is a significant difference. This requires other tests to be performed between the three sets $(0-2,0-5,2-5)$. The Mann-Whitney test concludes that there is a significant difference between the $0 \%$ and $2 \%$ biochar. There is also a difference between the $2 \%$ and $5 \%$ biochar. Between $0 \%$ and $5 \%$ biochar there is no significant difference. There is a significant difference of 0.021 between $0 \%$ and $2 \%$ biochar similar to $2 \%$ and $5 \%$ biochar.

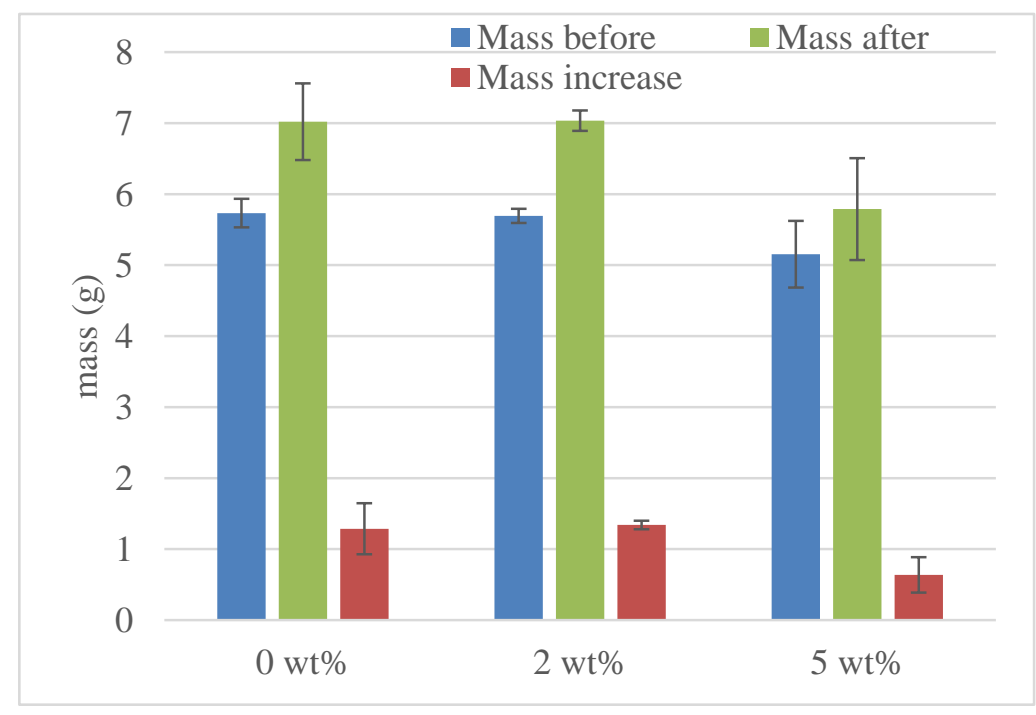

Figure 12. Effect of the blended soils on the mass of E. fetida 


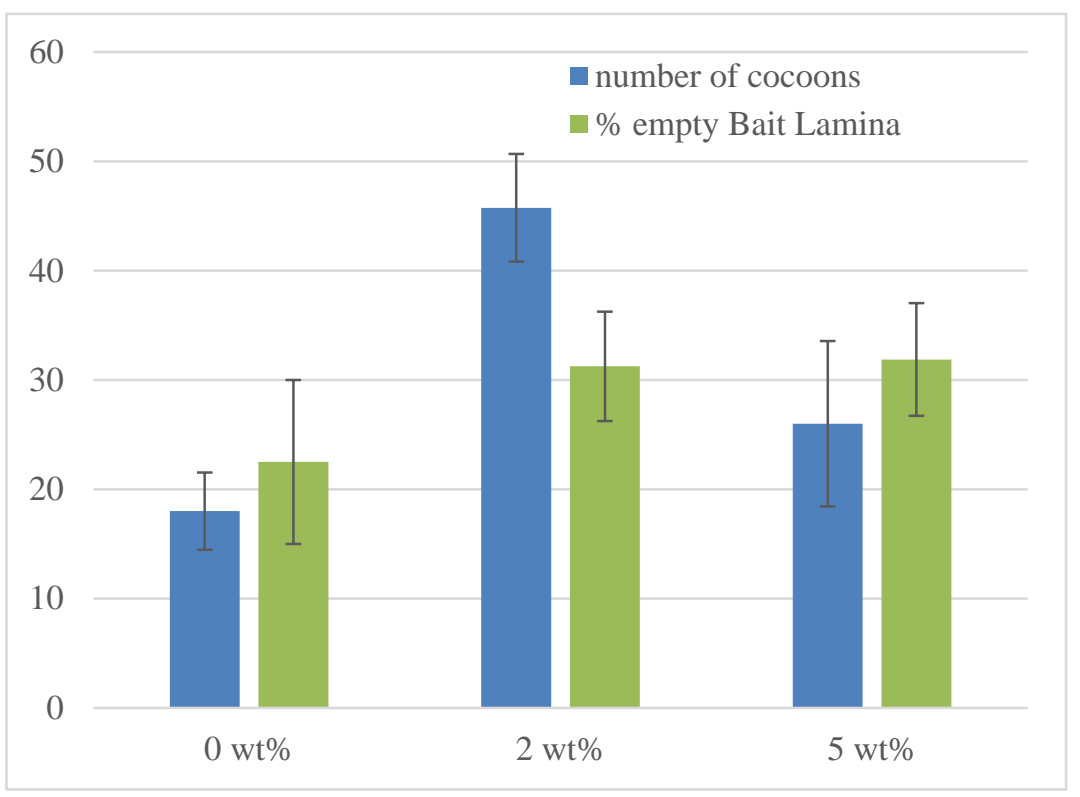

Figure 13. Effect of the blended soils on the reproduction and activity (bait lamina) of E. fetida

\section{Conclusion}

The dried thick fraction of the pig manure is a good starting material for the production of amendment biochar. The pyrolysis process was optimized to achieve a yield of $48.8 \%$. The pyrolysis of the dried thick fraction of the pig manure also provides an additional $30 \%$ of biogas that can be used for the generation of electricity or the heating of the pyrolysis reactor itself. This produced biochar is suitable as alternative to the present chemical fertilizers due to the high concentrations of $\mathrm{K}$ and $\mathrm{P}$. The total concentrations of $\mathrm{Cu}$ and $\mathrm{Zn}$ are too high compared to the environmental standards. However, blending this char with the char of another fraction of the pig manure, the thin fraction, increased also the concentration of $\mathrm{N}$ and at the same time lowers the total concentration of $\mathrm{Cu}$ and $\mathrm{Zn}$ (as its content is much lower) resulting in a total concentration below the Flemish Regulation on Environmental Authorisation (VLAREM) regulation. Nevertheless, the high ash content of this char, about 50\%, it proves to be also suitable for the production of activated carbon (AC). This is confirmed by recently done studies. This char is also suitable for blending with a soil poor in nutrients. The soils with $2 \mathrm{wt} . \%$ and $5 \mathrm{wt} . \%$ biochar score much better than the reference soil. The soils in which $10 \mathrm{wt} . \%$ biochar was mixed held too much water which was detrimental to the plants. The blending of biochar in soils not only has a positive effect on plant growth but also on the immobilization of heavy metal ions preventing their release towards ground water. The cocoon production is the most sensitive endpoint for E. fetita. From these results it can be stated that the soil with $2 \%$ biochar scores the best. The resulting biochar therefore offers potential as low cost, slow release soil conditioner and better carbon sequester for a long term effect. The thermal conversion has a clear potential to market exploitable products. The effect of biochar is threefold: the buffering and beneficial WHC effect on the soil, inhibition of toxic elements which affect bioavailability and the release of nutrients in a more controlled manner favouring rapid plant growth.

\section{Acknowledgement}

We thank the technical staff of Applied and Analytical Chemistry for support in the chemical analysis and Carine Put for assisting with the enzyme detection in the bean plants. This research did not receive any specific grant from funding agencies in the public, commercial, or not-for-profit sectors.

\section{References}

Araujo, G. C. L., Gonzalez, M. H., Ferreira, A. G., Nogueira, A. R. A., \& Nobrega, J. A. (2002). Effect of acid concentration on closed-vessel microwave-assisted digestion of plant materials. [Article; Proceedings Paper]. Spectrochimica Acta Part B-Atomic Spectroscopy, 57(12), 2121-2132. https://doi.org/10.1016/S0584-8547(02)00164-7

Azargohar, R., \& Dalai, A. K. (2006). Biochar as a precursor of activated carbon. Applied Biochemistry and Biotechnology, 131(1-3), 762-773. https://doi.org/10.1007/978-1-59745-268-7_62 
Bouwman, L. A., \& Vangronsveld, J. (2004). Rehabilitation of the nematode fauna in a phytostabilized, heavily zinc-contaminated, sandy soil. Journal of Soils and Sediments, 4(1), 17-23. https://doi.org/10.1007/BF02990824

Cantrell, K. B., Hunt, P. G., Uchimiya, M., Novak, J. M., \& Ro, K. S. (2012). Impact of pyrolysis temperature and manure source on physicochemical characteristics of biochar. Bioresource Technology, 107, 419-428. https://doi.org/10.1016/j.biortech.2011.11.084

Carter, M. R. (1993). Soil sampling and methods of analysis. Florida: Lewis Publishers.

Demirbas, A. (2001). Biomass resource facilities and biomass conversion processing for fuels and chemicals. Energy Conversion and Management, 42(11), 1357-1378. https://doi.org/10.1016/S0196-8904(00)00137-0

Dias, J. M., Alvim-Ferraz, M. C. M., Almeida, M. F., Rivera-Utrilla, J., \& Sanchez-Polo, M. (2007). Waste materials for activated carbon preparation and its use in aqueous-phase treatment: A review. Journal of Environmental Management, 85(4), 833-846. https://doi.org/10.1016/j.jenvman.2007.07.031

EEA (European Environment Agency). (2009). Part B: sectoral guidance chapters, 4b. Manure management EMEP/EEA air pollutant emission inventory guidebook, EEA.

Extension, U. O. D. C., \& United States. Cooperative State Research, E., and Extension Service. Northeast Coordinating Committee on Soil Testing. (1995). Recommended Soil Testing Procedures for the Northeastern United States: Cooperative Extension, University of Delaware.

Faridullah, Irshad, M., \& Sabir, M. A. (2012). Investigation of Heavy Metals using Various Extraction Methods in Livestock Manures. Communications in Soil Science and Plant Analysis, 43(21), 2801-2808. https://doi.org/10.1080/00103624.2012.719977

Galinato, S. P., Yoder, J. K., \& Granatstein, D. (2011). The economic value of biochar in crop production and carbon sequestration. Energy Policy, 39(10), 6344-6350. https://doi.org/10.1016/j.enpol.2011.07.035

Gleyzes, C., Tellier, S., \& Astruc, M. (2002). Fractionation studies of trace elements in contaminated soils and sediments: a review of sequential extraction procedures. Trac-Trends in Analytical Chemistry, 21(6-7), 451-467. https://doi.org/10.1016/S0165-9936(02)00603-9

International, A. (2011). ASTM D3173-11, Standard Test Method for Moisture in the Analysis Sample of Coal and Coke. West Conshohocken.

Kratz, W. (1998). The bait-lamina test - General aspects, applications and perspectives. Environmental Science and Pollution Research, 5(2), 94-96. https://doi.org/10.1007/BF02986394

Kuppens, T., Van Dael, M., Maggen, J., Vanreppelen, K., Yperman, J., Carleer, R., et al. (2014). TECHNO-ECONOMIC ASSESSMENT OF DIFFERENT CONVERSION PATHWAYS FOR PYROLYSIS CHAR FROM PIG MANURE. Papers of the 22nd European Biomass Conference: Setting the Course for a Biobased Economy, 901-911.

Kuppens, T., Van Dael, M., Vanreppelen, K., Carleer, R., Yperman, J., \& Schreurs, S., et al. (2014). Techno-Economic Assessment of Pyrolysis Char Production and Application-A Review. Iconbm: International Conference on Biomass, Pts 1 and 2, 37, 67-72.

Ro, K. S., Cantrell, K. B., \& Hunt, P. G. (2010). High-Temperature Pyrolysis of Blended Animal Manures for Producing Renewable Energy and Value-Added Biochar. Industrial \& Engineering Chemistry Research, 49(20), 10125-10131. https://doi.org/10.1021/ie101155m

Schulz, H., \& Glaser, B. (2012). Effects of biochar compared to organic and inorganic fertilizers on soil quality and plant growth in a greenhouse experiment. Journal of Plant Nutrition and Soil Science, 175(3), 410-422. https://doi.org/10.1002/jpln.201100143

Solutions, S. Statistics Solutions Advancement Through Clarity ${ }^{\mathrm{TM}}$. from http://www.statisticssolutions.com/

Standardization, I. O. f. (2012). Soil quality - Effects of pollutants on earthworms - Part 2: Determination of effects on reproduction of Eisenia fetida/Eisenia andrei: ISO.

Tack, F. M. G., Van Ranst, E., Lievens, C., \& Vandenberghe, R. E. (2006). Soil solution Cd, Cu and Zn concentrations as affected by short-time drying or wetting: The role of hydrous oxides of Fe and Mn. Geoderma, 137(1-2), 83-89. https://doi.org/10.1016/j.geoderma.2006.07.003

Tuck, C. O., Perez, E., Horvath, I. T., Sheldon, R. A., \& Poliakoff, M. (2012). Valorization of Biomass: Deriving 
More Value from Waste. Science, 337(6095), 695-699. https://doi.org/10.1126/science.1218930

Uchimiya, M., Bannon, D. I., Wartelle, L. H., Lima, I. M., \& Klasson, K. T. (2012). Lead Retention by Broiler Litter Biochars in Small Arms Range Soil: Impact of Pyrolysis Temperature. Journal of Agricultural and Food Chemistry, 60(20), 5035-5044. https://doi.org/10.1021/jf300825n

Vanassche, F., \& Clijsters, H. (1990). A Biological Test System for the Evaluation of the Phytotoxicity of Metal-Contaminated Soils. Environmental Pollution, 66(2), 157-172. https://doi.org/10.1016/0269-7491(90)90118-V

Xiu, S. N., Shahbazi, A., Shirley, V., \& Cheng, D. (2010). Hydrothermal pyrolysis of swine manure to bio-oil: Effects of operating parameters on products yield and characterization of bio-oil. Journal of Analytical and Applied Pyrolysis, 88(1), 73-79. https://doi.org/10.1016/j.jaap.2010.02.011

Zhang, A. F., Cui, L. Q., Pan, G. X., Li, L. Q., Hussain, Q., Zhang, X. H., et al. (2010). Effect of biochar amendment on yield and methane and nitrous oxide emissions from a rice paddy from Tai Lake plain, China. Agriculture Ecosystems \& Environment, 139(4), 469-475. https://doi.org/10.1016/j.agee.2010.09.003

\section{Copyrights}

Copyright for this article is retained by the author(s), with first publication rights granted to the journal.

This is an open-access article distributed under the terms and conditions of the Creative Commons Attribution license (http://creativecommons.org/licenses/by/3.0/). 